Roman Inderst *

Christian Wey **

\title{
Buyer Power and Supplier Incentives
}

* London School of Economics

** WZB - Wissenschaftszentrum Berlin

\section{SP II $2003-05$}

June 2003

ISSN Nr. $0722-6748$

Research Area

Markets and Political Economy

Research Unit

Competitiveness and Industrial Change
Forschungsschwerpunkt

Markt und politische Ökonomie

\section{Abteilung}

Wettbewerbsfähigkeit und industrieller Wandel 
Zitierweise/Citation:

Roman Inderst and Christian Wey, Buyer Power and Supplier Incentives, Discussion Paper SP II 2003 - 05, Wissenschaftszentrum Berlin, 2003.

Wissenschaftszentrum Berlin für Sozialforschung gGmbH, Reichpietschufer 50, 10785 Berlin, Germany, Tel. (030) 25491 - 0 Internet: www.wz-berlin.de 


\section{ABSTRACT}

\section{Buyer Power and Supplier Incentives}

by Roman Inderst and Christian Wey

This paper investigates how the formation of larger buyers affects a supplier's profits and, by doing so, his incentives to undertake non-contractible activities. We first identify two chan-nels of buyer power, which allows larger buyers to obtain discounts. We subsequently exam-ine the effects of buyer power on the supplier's incentives and on social welfare. Contrary to some informal claims in the policy debate on buyer power, we find that the exercise of buyer power even though reducing supplier's profits- may often increase a supplier's incentive to undertake welfare enhancing activities.

Keywords: Buyer Power, Investments, Competition Policy

JEL Classification: D43, L13, L40

\section{ZUSAMMENFASSUNG}

\section{Käufermacht und die Investitionsanreize der Hersteller}

Dieser Aufsatz entwickelt einen Modellrahmen zur Analyse der Wirkungen von Käufermacht auf Zwischenproduktmärkten. Zunächst werden Bedingungen identifiziert, die gewährleisten, daß Käufer mit großem Nachfragevolumen von Herstellern günstigere Konditionen erhalten als relativ kleine Käufer und somit über „Käufermacht“ verfügen. So dann untersucht die Arbeit, ob die Existenz von Käufermacht zu einer Verringerung der Innovationsanreize auf Seiten der Herstellern führt. Es wird gezeigt, daß eine solche Vermutung im Allgemeinen unzutreffend ist und daß Käufermacht im Gegenteil häufig höhere Investitionsanstrengungen auf der Herstellerseite induziert. 


\section{Introduction}

In many industries suppliers face increasingly concentrated demand and overall more powerful buyers. A prominent example is the growing power of retailers, in particular in the fast-moving consumer goods industry. According to studies commissioned by the European Commission (EC 1999) and the OECD (OECD 1999) the grocery retail market in several member states of the European Union is dominated by a small number of large retailers. Although market concentration is less extreme in the US, concerns have been expressed more recently about the increasing number of retail mergers (see, e.g., Balto 1999) and the growing power of retailers over their suppliers (see, e.g., FTC 2001). ${ }^{1}$

Retailing is, however, not the only industry where buyer power is on the rise. Casual evidence suggests that suppliers' bargaining power has eroded in numerous other manufacturing industries such as automobiles and also in service industries such as healthcare. ${ }^{2}$ Besides merging and forming a single entity, an alternative way for buyers to increase their clout is to form purchasing alliances. This is a very common step in retailing (see, e.g., Robinson and Clarke-Hill 1995). To obtain discounts such alliances may also be only of a very temporary nature, e.g., in order to bundle purchases at internet platforms. ${ }^{3}$

Should the formation of larger and stronger buyers be of concern to antitrust authorities? According to the textbook model (e.g., Blair and Harrison 1993 or Scherer and Ross 1990, Chapter 14) a higher concentration among buyers leads to a strategic reduction in purchases with the aim of reducing prices. ${ }^{4}$ This argument rests on a mirror image of the exercise of market power by sellers. A single price prevails at which all market transactions take place. Buyers (sellers) affect this price by strategically withholding demand (supply). ${ }^{5}$ While this picture may be adequate for most final goods markets and also for some input markets in which standard commodities are traded, it seems to be less suitable to describe the interaction between buyers and suppliers in our previous

\footnotetext{
${ }^{1}$ Although concentration in the US grocery retail market is low at a national level, there have been considerable increases at the regional level (see, e.g., Cotterill 1997).

${ }^{2}$ For instance, Gaynor and Haas-Wilson (1999) suggest that mergers in the US healthcare industry in the 1990s were motivated by hospitals' and other payers' attempts to improve their bargaining position.

${ }^{3}$ For a discussion of the potential implications of B2B platforms see FTC (2000).

${ }^{4}$ This view is also taken explicitly in US antitrust regulation. The Horizontal Merger Guidelines (1992, revised 1997; Paragraph 0.1) provide that "(m)arket power...encompasses the ability of a single buyer (a "monopsonist"), a coordinating group of buyers, or a single buyer, not a monopsonist, to depress the price paid for a product to a level that is below the competitive price and thereby depress output."

${ }^{5}$ See Hendricks and McAfee (2000) for a model that incorporates strategic behavior of both sellers and buyers.
} 
examples, where prices are often set in bilateral negotiations or in auctions organized separately by individual buyers. While the exercise of buyer power should lead to more favorable deals obtained by larger and stronger buyers, it should not result in an overall reduction of purchases. ${ }^{6}$

If the formation of larger buyers does not negatively affect the performance of the input market, it could still reduce competition on the final goods market. However, in many instances anti-competitive effects on the final goods market are also not likely to occur. Members of buyer groups, while pooling their orders to obtain better deals from suppliers, may continue to compete fiercely for consumers. Anti-competitive effects are also absent in mergers between retailing chains that operate in different geographic markets. ${ }^{7}$ Furthermore, the growing use of divestitures in merger control may leave competition in regional retailing markets unchanged after a merger of two retailing chains (see Balto 1999).

If traditional concerns about the monopolization of upstream or downstream markets are not an issue, are there still reasons why regulators should care about the exercise of buyer power? ${ }^{8}$ In this paper we focus on the often expressed view that buyer power negatively affects upstream incentives to invest in product and process innovation. In particular, this view has been repeatedly expressed regarding the grocery retail industry. ${ }^{9}$ According to a report for the European Commission, buyer power may force manufacturers "to reduce investment in new products or product improvements, advertising and brand building" (EC 1999, p. 4), while according to a report for the FTC consumers "could be adversely affected by the exercise of buyer power in the longer run, if prices to suppliers are reduced below a competitive level and if the suppliers respond by under-investing in innovation or production" (FTC 2000, p. 57 and Footnote 190).

The aim of this paper is twofold. We first show how buyer power can arise under negotiated supply contracts. We then apply our model to investigate the argument that buyer power reduces suppliers' incentives. We find that suppliers' total profits, which may well erode following the formation of larger buyers, provide a misleading picture. What is more important is the way in which the "composition" of suppliers' profits is

\footnotetext{
${ }^{6}$ Our view is certainly not original. For instance, in OECD (1981) the definition of buyer power rests on the ability of strong buyers to obtain more favorable terms, while in FTC (2001, p. 56) it is explicitly recognized that the exercise of buyer power should not reduce volume.

${ }^{7}$ Similarly, in the automobile industry the cars of two merging companies may only appeal to the residents of different countries.

${ }^{8}$ In his well-known critique of Galbraith's (1952) optimistic assessment of countervailing power, Stigler (1954) already held the opinion that it will only redistribute monopoly rents while leaving consumer surplus unaffected.

${ }^{9}$ The US health service is another industry where the impact of buyer power on quality and investment has been addressed (see, e.g., Pitofsky 1997).
} 
affected by the presence of larger buyers.

Precisely, we consider a model where a single supplier serves a number of downstream firms. Input prices and quantities are determined in bilateral negotiations, though we show that our framework also encompasses the case where buyers compete in an auction. To focus on the exercise of buyer power on the input market, we abstract from interactions on the final goods market. For instance, firms may use the supplier's input to produce final goods with independent demands or, in case of retailers, outlets may be located in different regions. Under reasonable assumptions larger buyers manage to negotiate lower prices. We isolate two sources of buyer power.

First, a larger buyer may be able to use a stronger threat of withdrawing his demand. For an intuitive argument suppose that the supplier has fixed capacity. When negotiations with a small buyer fail, the supplier can easily sell the released capacity to other firms without suffering a large reduction in the prevailing price. In contrast, if negotiations with a large buyer fail, selling the quantity that was previously earmarked for this buyer to other firms should have a larger impact on prices and revenues. As documented below, a similar line of argument has been used in recent antitrust cases.

Second, buyer power can originate from characteristics of the supplier's production technology. We show that larger buyers can obtain a discount if production costs are convex, implying globally increasing unit costs. Intuitively, while a (very) small buyer has to negotiate over additional production "at the margin", where incremental costs are high, a larger buyer's supply spans a wider production interval, implying overall lower unit costs.

We next consider a supplier's incentives to choose between different non-contractible strategies of production or process innovation. As each buyer obtains a share of his respective net contribution to total industry profits, the supplier aims at the same time to increase total industry profits and to reduce the contribution of each individual buyer. How the supplier solves this problem depends on the downstream market structure. Facing larger buyers the supplier is able to roll over more of his incremental production costs at large quantities and less of his incremental production costs at small quantities. This consideration affects his incentives for process innovation. Moreover, facing larger buyers the supplier's profits depend much on how well he can respond to a large shortfall in his demand. This consideration affects his incentives for product choice and product improvement. In both instances of process and product innovation we argue that the formation of larger buyers should induce the supplier to choose strategies that increase total output and, by rasing consumer surplus, possibly increase social welfare.

The rest of this paper is organized as follows. In Section 2 we review the related literature. Section 3 presents the model. In Section 4 we derive equilibrium profits. We 
analyze the impact of buyer size on profits in Section 5, while in Section 6 we study how the emergence of larger buyers affects the supplier's incentives and thereby social welfare. Section 7 concludes.

\section{Related Literature}

There is a small literature analyzing the sources and implications of buyer power in an industrial organization setting; i.e., the ability of larger buyers to obtain better terms. The role of increasing unit costs as a source of buyer power has also been recognized in Chipty and Snyder (1999) and Inderst and Wey (2001). These papers apply a cooperative solution concept and they only show that two firms are better off by merging. In particular, they do not derive general conditions that ensure that larger buyers are better off than smaller buyers. ${ }^{10}$ In Katz (1987) a larger buyer can exert more pressure on a supplier as he can more credibly threaten to integrate backwards. ${ }^{11}$ According to another line of argument, which is expressed in Scherer and Ross (1990, Chapter 14) and formalized in Snyder (1996), a larger buyer's purchasing order is more likely to succeed in breaking up potential collusion between suppliers. ${ }^{12}$

Another strand of the literature analyses the exercise of "countervailing" power by a more concentrated downstream market (von Ungern-Sternberg 1996 and Dobson and Waterson 1997, which build on Horn and Wolinsky 1988a). Buyers are always symmetric in these models, which does not allow to study whether larger buyers can obtain more favorable terms. ${ }^{13}$ Finally, Marx and Shaffer (2001) model buyer power as a switch from a regime where suppliers propose contracts to a regime where this is done by

\footnotetext{
${ }^{10}$ In fact, it can be shown that for the chosen solution concept (the Shapley value) increasing unit costs are not generally sufficient to make a larger buyer better off. In Inderst and Wey (2001) the Shapley value is obtained from a non-cooperative procedure by making contracts contingent on the set of successful negotiations. Inderst and Wey (2001) focus on the equilibrium up- and downstream market structure in a bilateral duopoly, but they also study the impact of market structure on the choice between two linear production technologies.

${ }^{11}$ This approach has also been adopted in Scheffman and Spiller (1992) and Innes and Sexton (1993).

${ }^{12}$ In a similar vein it is argued informally by Stigler (1964) and Porter (1976) that a secret price cut by a supplier is more likely to become known in a market with many buyers. The threat of retaliation by other suppliers may thus make a (deviating) price cut less likely if there are many small buyers. The ability of large buyers to defeat supplier cartels is questioned in Kolasky (2000), who reports many cases where successful cartels sell to large buyers.

${ }^{13}$ More precisely, buyer power is studied in Dobson and Waterson (1997) under Bertrand competition with differentiated products and in von Ungern-Sternberg (1996) under Cournot competition with homogenous products. In the former model, firms are always symmetric as a merger between two buyers involves the abandonment of one party's brand, while in the latter model perfect substitutability of products ensures that buyers remain symmetric after mergers.
} 
buyers, which typically also solves or creates additional problems of coordination failure in contracting. ${ }^{14}$

There is a small empirical literature linking market concentration to buyer and supplier profitability (see the summary in Ellison and Snyder 2001). As these papers, with the exception of case studies, confine themselves to the regression of up- and downstream concentration measures on measures of profitability, they do not have much to say on whether larger buyers enjoy discounts. More recent studies of the US healthcare industry investigate whether certain buyers, e.g., certain hospitals or certain insurers, enjoy discounts compared to other buyers. These studies focus less on buyers' size and more on how easily they can substitute between different suppliers, e.g., to which degree insurers can restrict their patients' choice (see, for instance, Ellison and Snyder 2001 and Sorensen 2001).

By studying a supplier's incentives to undertake non-contractible activities of process or product innovation, our paper is related to the vast literature on the hold-up problem (Grout 1984). The main paradigm, following the formalization in Grossman and Hart (1986), studies the role of integrating the investing parties. In contrast, we study -amongst other things- how the integration of some buyers affects the incentives of the upstream supplier. There is also a small strand of the hold-up literature that analyzes the impact of competition (see Felli and Roberts 2001 for an overview). In these models agents typically match pairwise, while competition is defined as the degree of substitutability of different agents on either side of the market. A change in competition has thus quite different implications than the formation of a larger buyer has in our setting with multilateral supply contracts. Other papers investigate the impact of vertical integration on the incentives of excluded downstream firms (Bolton and Whinston 1993) or of excluded upstream firms (McLaren 2000 and Choi and Yi 2000), though they all address issues that are not overlapping with those in our paper. Spulber (2002) studies how incentives to invest depend on the market microstructure, i.e., on whether buyers and sellers match in a decentralized market or in a dealer market. Finally, Kranton and Minehart (2000) analyze incentives to invest into the formation of exchange networks and the relative benefits of vertical integration before prices are determined.

\footnotetext{
${ }^{14}$ Whether the integration of agents allows them to extract more rents in negotiations has also been studied in other economic environments; see, e.g., Stole and Zwiebel (1996) and Horn and Wolinsky (1988b) for union-firm bargaining. Segal (2001) provides an overview and studies the benefits from integration under various cooperative solution concepts.
} 


\section{The Model}

We consider a single supplier producing the quantity $x$ of some input. His production technology is described by the cost function $C(x)$. We allow both for the case where $x$ is unconstrained and for the case where the supplier's capacity has an upper boundary denoted by $X$. Inputs are used by $N \geq 2$ downstream firms. For simplicity, we assume that the downstream firms' technology converts each unit of the supplier's input into a unit of the final good at a zero marginal cost. Firms serve independent markets characterized by the same inverse demand function $p(x)$. The restriction to independent markets for final goods allows us to focus on the input market. The specification of the simple production technology for intermediary firms and the symmetry assumption are made to facilitate the exposition of our results, which can be generalized. We denote revenues generated at each firm by $R(x):=x p(x)$. Finally, we assume that the cost function is twice continuously differentiable over $x<X$ and that the same holds for the inverse demand function over all $x$ satisfying $p(x)>0$.

Some downstream firms may belong to the same owner. Given symmetry of firms, the market for inputs is thus described by specifying the number $r_{i}$ of firms controlled by any buyer (or owner) $i=1, \ldots, I$. Note that $\sum_{i=1}^{I} r_{i}=N$.

We next specify how input prices and quantities are determined. Each buyer negotiates separately with the supplier. A contract with buyer $i$, who purchases inputs for $r_{i}$ firms, specifies a menu of prices $t_{i}\left(x_{i}\right)$ as a function of the supplied quantity $x_{i} .{ }^{15}$ As there is no uncertainty, in equilibrium each buyer will receive a deterministic quantity. We denote this choice by $\bar{x}_{i}$ and the respective transfer by $\bar{t}_{i}=t_{i}\left(\bar{x}_{i}\right)$. The supplier's sales representatives negotiate with each buyer simultaneously and independently over the respective menu $t_{i}$. The quantity $\bar{x}_{i}$ is chosen to maximize the joint surplus of the two sides. The equilibrium transfer $\bar{t}_{i}$ is determined such that a buyer receives the fraction $\rho \in(0,1]$ of the generated net surplus. As argued in more detail below, setting $\rho=1$ will obtain the same outcome as that arising from a menu auction between buyers. When determining $\bar{x}_{i}$ and $\bar{t}_{i}$ the two sides form rational expectations about the outcomes of all other negotiations.

As there is no uncertainty, the buyers' and the supplier's representatives are indifferent regarding the choice of $t_{i}(x)$ for all quantities $x \neq \bar{x}_{i}$. To pin down the menu we make the following specification. We specify that it is the supplier who has the right to pick a quantity on the menu, while the menu $t_{i}$ truthfully reflects the valuation of buyer $i$. To formalize the second specification, note first that by optimality the buyer will

\footnotetext{
${ }^{15} \mathrm{An}$ example would be a percentage quantity discount, where the size of the discount is a function of the percentage of its total sales the supplier sells to a retailer.
} 
allocate a supplied quantity $x$ symmetrically over all controlled markets if the demand function is falling, which is assumed to hold. Hence, to truthfully reflect the buyer's valuation, $t_{i}$ must satisfy for all quantities $x^{\prime}$ and $x^{\prime \prime}$ the requirement ${ }^{16}$

$$
t_{i}\left(x^{\prime \prime}\right)-t_{i}\left(x^{\prime}\right)=r_{i}\left[R\left(x^{\prime \prime} / r_{i}\right)-R\left(x^{\prime} / r_{i}\right)\right] .
$$

As there is a single supplier, the requirement of truthfulness for each buyer is natural. It leaves the supplier with all rents generated by adjusting individual supplies, which could become profitable if there was no agreement with a subset of buyers. One implication of truthfulness will be that supplies are chosen to maximize total industry profits both on and off equilibrium, which excludes the possibility of mutually beneficial renegotiations. ${ }^{17}$

The considered contracts are sufficiently complex to disentangle the issue of surplus maximization (achieved by choosing $\bar{x}_{i}$ ) from that of surplus sharing (achieved by choosing $\left.\bar{t}_{i}\right)$. There is ample evidence in retailing that contracts, in particular with branded suppliers, are relatively complex, specifying, for instance, promotional allowances, volume discounts, up-front or pay-to-stay fees, or the provision of additional services by the supplier. ${ }^{18}$ As will become clear in what follows, the intuition behind our results does, however, not hinge on the chosen contractual form, i.e., that contracts prescribe truthful menus. We thus conjecture that our insights extend as well to the opposite extreme where contracts are constrained to be extremely simple and specify for each buyer only a single input price, i.e., a linear tariff. ${ }^{19}$ It is, however, crucial that buyers negotiate separately with the supplier and can therefore obtain different deals. This is clearly a prerequisite for the exercise of buyer power as defined in the introduction, i.e., as the ability of larger (or otherwise stronger) buyers to obtain more favorable terms. In this regard it is important to note for applications to the U.S. that, while the resulting discounts may offend the spirit of the Robinson-Patman Act in the U.S., antitrust authorities and courts have become less eager to enforce it in a narrow sense. ${ }^{20}$

\footnotetext{
${ }^{16}$ For the truthfulness requirement in first-price menu auctions, see Bernheim and Whinston (1986).

${ }^{17}$ Once the issue of possible co-ordination failure to achieve the optimal supplies is ruled out, equilibrium supplies do not depend on the truthfulness requirement. This is clearly different to models with downstream interaction of buyers (see, e.g., Kühn 1997).

${ }^{18}$ As $t_{i}(0)<0$ will typically hold, the respective payment can be interpreted as a slotting allowance. While the use of slotting allowances has certainly increased, at least for branded goods, there is no consensus on how widespread and important they are (see, e.g., Sullivan 1997 and FTC 2001).

${ }^{19}$ The question of choosing between a linear-tariff (or "arms-length" or "double-marginalization") model or an efficient-contracting (or "two-part tariff" or "joint-profit maximization") model has a long history. We found that already Morgan (1949) contains a detailed discussion. Scherer and Ross (1990) report that the efficient contracting model goes back to Bowley (1928), though only applied to a bilateral monopoly. With linear tariffs a shift of rents to downstream firms also reduces the double-marginalization problem by lowering input prices.

${ }^{20}$ An illustrative case, which is discussed in Scherer and Ross (1990), is that of the retailer A\&P in
} 


\section{Profits under Various Market Structures}

To state our results in a convenient way, we need some additional notation. Suppose the supplier serves only $n$ of the $N$ downstream firms. Suppose also that, given this restriction, supplies are chosen so as to maximize total industry profits. We assume that the total quantity that maximizes industry surplus is uniquely determined and strictly positive. We denote total quantity supplied to the $n$ active downstream firms by $x_{n}^{*}$. We denote the respective revenues realized at each of the $n$ active firms by $R_{n}^{*}:=\left(x_{n}^{*} / n\right) p\left(x_{n}^{*} / n\right)$. Total realized industry profits are denoted by $\Pi_{n}^{*}:=n R_{n}^{*}-C\left(x_{n}^{*}\right)$. As demand at each firm is strictly falling, we obtain that $\Pi_{n}^{*}$ is strictly increasing in $n$. We specify $C(0)=0$, from which it follows that $\Pi_{0}^{*}=0$.

We next state an immediate implication of the truthfulness requirement. When making his choice on how to supply to the different buyers, the supplier fully internalizes both the incremental revenues and the incremental costs. As a consequence, he produces the total quantity $x_{N}^{*}$ and supplies $\bar{x}_{i}=x_{N}^{*} r_{i} / N$ to buyer $i$. Note, in particular, that this holds irrespective of the prevailing transfers $\bar{t}_{i}$, which pin down the distribution of rents. Likewise, if -out of equilibrium- there is failure to agree with some buyers such that negotiations are only successful with a subset $I^{\prime} \subseteq I$ of buyers, the total quantity $x_{n}^{*}$ is produced, where $n=\sum_{i \in I^{\prime}} r_{i}$, and each buyer $i \in I^{\prime}$ is supplied with the quantity $x_{n}^{*} r_{i} / n$.

Lemma 1. If there is agreement with a (sub)set of buyers $I^{\prime} \subseteq I$, the total quantity $x_{n}^{*}$ is produced, where $n=\sum_{i \in I^{\prime}} r_{i}$. Moreover, buyer $i \in I^{\prime}$ receives the quantity $x_{n}^{*} r_{i} / n$.

Fragmented downstream industry

Suppose first that each buyer owns a single firm. Consider negotiations between buyer $i$ and the supplier. As all bilateral negotiations are successful, we obtain from Lemma 1 the quantities $\bar{x}_{i}=x_{N}^{*} / N$. Using $\bar{t}_{i}=t_{i}\left(\bar{x}_{i}\right)$, the aggregate payoff of the supplier, which we denote by $V$, becomes $V:=\sum_{i \in I} \bar{t}_{i}-C\left(x_{N}^{*}\right)$. To determine the equilibrium transfer $\bar{t}_{i}$, we must derive the two parties' outside options if negotiations fail. Clearly, the buyer will receive zero utility. If bargaining with buyer $i$ breaks down, the supplier obtains his outside option payoff

$$
V_{i}^{0}:=\sum_{j \in I \backslash\{i\}} t_{j}\left(x_{N-1}^{*} /(N-1)\right)-C\left(x_{N-1}^{*}\right),
$$

where the supply level is optimally adjusted. By the truthfullness condition (1) the supplier can capture the entire incremental revenues from re-adjusting the supplies to

1979. A\&P threatened to withdraw its demand from the milk producer Borden unless it obtained a sufficiently large discount. Even though the discount gave A\&P a substantial cost advantage compared to other buyers, it was not objected in the final court decision. 
all other buyers $j \neq i$. Using this, we obtain the requirement

$$
\sum_{j \in I \backslash\{i\}} t_{j}\left(x_{N-1}^{*} /(N-1)\right)=\sum_{j \in I \backslash\{i\}} \bar{t}_{j}+(N-1)\left[R\left(x_{N-1}^{*} /(N-1)\right)-R\left(x_{N}^{*} / N\right)\right] .
$$

Substituting (3) into (2), the expression for the supplier's outside option becomes

$$
V_{i}^{0}=\sum_{j \in I \backslash\{i\}} \bar{t}_{j}+\Pi_{N-1}^{*}-(N-1) R\left(x_{N}^{*} / N\right) .
$$

As the supplier receives the fraction $1-\rho$ of the realized net surplus and as the supplier's total profits equal $\sum_{j \in I} \bar{t}_{j}-C\left(x_{N}^{*}\right)$, we obtain the requirement

$$
\sum_{j \in I} \bar{t}_{j}-C\left(x_{N}^{*}\right)=V_{i}^{0}+(1-\rho)\left[R\left(x_{N}^{*} / N\right)+\sum_{j \neq i} \bar{t}_{j}-C\left(x_{N}^{*}\right)-V_{i}^{0}\right] .
$$

By (4) and (5) all menus $t_{i}$ are identical. Solving (5) for the supplier's profits, we obtain

$$
V=\Pi_{N}^{*}-N \rho\left(\Pi_{N}^{*}-\Pi_{N-1}^{*}\right) .
$$

Expression (6) has a simple intuition. With each individual buyer the supplier essentially bargains over how to share the additional surplus generated by serving $N$ instead of $N-1$ firms. The additional surplus is given by the difference in maximum industry profits $\Pi_{N}^{*}-\Pi_{N-1}^{*}$. As each buyer extracts the fraction $\rho$ of this difference, we obtain expression (6).

The derivation of the supplier's profits in (6) comes with one caveat. It is assumed that (6) is non-negative. This is surely the case if industry profits $\Pi_{n}^{*}$ are concave in $n$. Below we derive conditions when this holds and we will later focus our analysis on this case.

\section{One buyer controlling two firms}

Suppose now a single buyer, say $i=1$, controls two firms, which reduces the number of independent buyers from $N$ to $N-1$. If negotiations with the integrated buyer break down, we know from Lemma 1 that the supplier chooses the aggregate quantity $x_{N-2}^{*}$. This reduces his costs by $C\left(x_{N}^{*}\right)-C\left(x_{N-2}^{*}\right)$ and generates the additional revenues $(N-$ 2) $\left[R\left(x_{N-2}^{*} /(N-2)\right)-R\left(x_{N}^{*} / N\right)\right]$, which the supplier fully capture by the truthfulness requirement. Hence, the supplier's outside option when negotiating with the larger buyer becomes

$$
V_{1}^{0}=\sum_{j \neq 1} \bar{t}_{j}+\Pi_{N-2}^{*}-(N-2) R\left(x_{N}^{*} / N\right) .
$$

When negotiating with any of the small buyers $i>1$ his outside option is still given by (4). Equilibrium profits are again obtained by substituting outside options into the 
requirement that the supplier obtains the fraction $1-\rho$ of the respective net surplus. Putting results together, we now obtain for the supplier's profits

$$
V=\Pi_{N}^{*}-\rho\left[(N-1) \Pi_{N}^{*}-(N-2) \Pi_{N-1}^{*}-\Pi_{N-2}^{*}\right] .
$$

This expression is again intuitive. The large buyer can extract the fraction $\rho$ of the difference $\Pi_{N}^{*}-\Pi_{N-2}^{*}$, while each small buyer can extract the fraction $\rho$ of the difference $\Pi_{N}^{*}-\Pi_{N-1}^{*}$.

\section{Generalization}

It is straightforward to extend the derivation of profits to any downstream market structure. We obtain the following general result.

Proposition 1. A buyer controlling $r_{i}$ firms obtains the profits $\rho\left[\Pi_{N}^{*}-\Pi_{N-r_{i}}^{*}\right]$, while the supplier obtains the profits $\Pi_{N}^{*}-\rho \sum_{i=1}^{I}\left[\Pi_{N}^{*}-\Pi_{N-r_{i}}^{*}\right]$.

We conclude this section with some remarks on Proposition 1. As noted previously, the case with $\rho=1$ is equivalent to an auction where buyers submit truthful menus. In this case buyers extract their full net surplus. ${ }^{21}$ Note also that we specified that a buyer's outside option has zero value, implying, in particular, that the buyer has no access to an alternative supplier. It is now straightforward to allow for the presence of an alternative source of supply for each buyer. If procuring from an inferior (fringe) supplier allows to realize the profits $U \geq 0$ at an individual firm, buyer $i$ obtains the profits $\rho\left[\Pi_{N}^{*}-\Pi_{N-r_{i}}^{*}\right]+U r_{i}(1-\rho)$.

\section{The Exercise of Buyer Power}

\subsection{Discounts to Larger Buyers}

In the previous section we first derived the supplier's profits under the two market structures where the downstream market was either fully fragmented or where there was a single larger buyer controlling two firms. Comparing the supplier's profits for the two cases, we obtain that he is worse off after the integration of two firms if it holds that

\footnotetext{
${ }^{21}$ This observation is reassuring for the following reason. Our negotiation procedure prescribes that the parties share the generated net surplus, which is calculated by subtracting the values of the two parties' outside options. As argued in detail in Binmore et al. (1986), the threat to take up the outside option may not be credible if the respective side could receive already more than this when negotiating whilst ignoring its outside option. However, as demonstrated by the same authors, we are back to the standard model where outside options always matter if negotiations proceed under the risk of breakdown. A menu-auction between buyers and sellers is also considered in O'Brien and Shaffer (1997), albeit applied to a setting with two upstream and one downstream firm.
} 
$\Pi_{N}^{*}-\Pi_{N-1}^{*}<\Pi_{N-1}^{*}-\Pi_{N-2}^{*}$, i.e., if the function of industry profits $\Pi_{n}^{*}$ exhibits decreasing increments from $N-2$ to $N$. The loss incurred by the supplier equals the gain of the two firms that merged to form a larger buyer.

Using Proposition 1 we can ask more generally when a larger buyer can obtain a more favorable deal. For this purpose denote by $\tau_{i}$ the average (or unit) price paid by buyer $i$. From Proposition 1 we obtain that the buyer's realized margin is given by

$$
p\left(x_{N}^{*} / N\right)-\tau_{i}=\frac{\rho\left[\Pi_{N}^{*}-\Pi_{N-r_{i}}^{*}\right]}{r_{i}} \frac{N}{x_{N}^{*}} .
$$

Larger buyers thus enjoy a discount whenever the term $\left[\Pi_{N}^{*}-\Pi_{N-r}^{*}\right] / r$ is strictly increasing in the number of controlled firms $r$. In this case a merger between buyers of arbitrary size is strictly beneficial for the involved buyers and reduces the supplier's profits. Note, however, that a merger does not affect the profits of other buyers.

An alternative way to form a larger buyer is the case where a smaller buyer sells assets (i.e., firms) to a larger buyer. Suppose that $r$ firms are sold by buyer $i=1$ to buyer $i=2$, where $r_{2}>r_{1}>r$. Using Proposition 1, the supplier's payoff then changes by the difference

$$
\rho\left[\Pi_{N-r_{1}+r}^{*}-\Pi_{N-r_{1}}^{*}\right]-\rho\left[\Pi_{N-r_{2}}^{*}-\Pi_{N-r_{2}-r}^{*}\right] .
$$

For (10) to be strictly negative irrespective of the choices of $r_{1}, r_{2}$, and $r$, it is no longer sufficient that $\left[\Pi_{N}^{*}-\Pi_{N-r}^{*}\right] / r$ is strictly increasing in $r$. We now need the stronger condition that industry profits $\Pi_{n}^{*}$ are strictly concave in $n$, i.e., that for all $n \geq 2$ it holds that

$$
\Pi_{n}^{*}-\Pi_{n-1}^{*}<\Pi_{n-1}^{*}-\Pi_{n-2}^{*} .
$$

Before exploring in the next section when this condition is satisfied, we first summarize the just obtained implications of Proposition 1 in the following corollary.

Corollary 1. Suppose (11) holds, i.e., industry profits are strictly concave in $n$. Then the creation of a larger buyer, e.g., through a merger or a sale of assets, reduces the supplier's profits, while a larger buyer obtains more favorable terms.

\subsection{Two Sources of Buyer Power}

We explore next under which conditions (11) holds. We find that buyer power may originate both from characteristics of the final demand and from characteristics of the supplier's production technology.

Buyer power originating from the characteristics of final demand 
To isolate buyer power originating from the characteristics of final demand, suppose that the supplier has a fixed capacity $X$ and that production costs are zero until the capacity constraint is reached. Moreover, let the capacity be sufficiently small such that it constrains the maximization of industry surplus even if only a single firm is supplied. Industry profits are then given by $\Pi_{n}^{*}=n R(X / n)$ for all $n$.

Take first the case where the downstream market is fully fragmented. If negotiations with one buyer fail, the supply at each of the remaining $N-1$ firms increases from $X / N$ to $X /(N-1)$, which depresses the prevailing price. The resulting loss in revenues equals

$$
N R(X / N)-(N-1) R(X /(N-1))
$$

The larger this loss, the lower becomes the value of the supplier's outside option when negotiating with a single buyer. Consider next the case where a single large buyer controls $r$ firms. If negotiations with the large buyer break down, the supplier will shift the released capacity $r X / N$ to the remaining $N-r$ firms, which reduces the prevailing price from $p(X / N)$ to $p(X /(N-r))$. The resulting loss in revenues, which again determines the supplier's outside option, is now given by

$$
N R(X / N)-(N-r) R(X /(N-r))
$$

Clearly, the large buyer can obtain more profits than $r$ independent buyers if total revenues lost by a break-down in negotiations, i.e., (12), increase over-proportionally with the buyer's size. As is easily checked and formalized in Proposition 2, a sufficient condition is that revenues $R(x)$ are strictly concave, implying -as capacity is fixed- that also industry profits $\Pi_{n}^{*}$ are strictly concave in $n$.

Interestingly, the fact that larger buyers can inflict on suppliers a damage that grows over-proportionally with their size seems to be regarded by antitrust authorities as a major source of buyer power. One case where this was made explicit is the acquisition of Prudential's health insurance assets by Aetna in the US. ${ }^{22}$ As described in detail in Schwartz (1999, p.8), it was feared that "a physician's total costs of replacing patients unexpectedly can increase by more-than-proportionally with the number of patients that must be replaced. ... (T)he physician's increased prospective loss per patient if dropped by Aetna increases Aetna's ability to force the physician to accept a lower price post merger."

A related argument underlies some recent decisions by the European Commission. In its decisions on the mergers of the retailers Kesko and Tuko and of the retailers Carrefour and Promodes the Commission expressed the view that for some suppliers

\footnotetext{
${ }^{22}$ United States, et al. v. Aetna, Inc, et al., No. 3-99CV1398-H (N.D. Tex.) (complaint filed June 21, 1999).
} 
the merged firm would control a fraction of their total sales exceeding some "critical" threshold. ${ }^{23}$ According to the Commission a supplier's economic viability is endangered if he is shut out from supplying to a firm whose share in his total sales exceeds this threshold. Consequently, if a merger allows a buyer to surpass this threshold, he can exert enormous pressure on the respective suppliers. This argument, if it is taken literally, relies much on the ideas that suppliers cannot swiftly scale down production to save costs or find alternative outlets for their production, while at the same time they cannot bridge a temporary shortfall in cash flow. Our previous discussion and the arguments of the US authorities in the Aetna/Prudential case show, however, that one does not have to appeal to this whole host of frictions in order to claim that larger buyers can exert substantially more pressure on suppliers by threatening to withhold their demand.

\section{Buyer power originating from the characteristics of the production technology}

To isolate buyer power originating from the characteristics of the supplier's production technology, suppose now that demand at each firm takes the following extreme form. At each firm the quantity $\tilde{x}>0$ can be sold at any price that does not exceed $\tilde{p}>0$, while an increase in sales by lowering prices is not feasible. Suppose further $\tilde{x}$ is sufficiently small such that to maximize industry profits it is optimal to sell $\tilde{x}$ at all firms whose owners have successfully negotiated with the supplier. Hence, it holds that $\Pi_{n}^{*}=n \tilde{x} \tilde{p}-C(n \tilde{x})$.

Consider again first the case where the downstream market is fully fragmented. If negotiations with a single buyer break down, the supplier reduces his production from $x_{N}^{*}=N \tilde{x}$ to $x_{N-1}^{*}=(N-1) \tilde{x}$. The net surplus obtained by supplying to an additional firm is then $\tilde{x} \tilde{p}-[C(N \tilde{x})-C((N-1) \tilde{x})]$. An individual buyer bears the fraction $\rho$ of the incremental costs $C(N \tilde{x})-C((N-1) \tilde{x})$. When negotiating with a larger buyer who controls $r$ firms, the net surplus becomes

$$
r \tilde{x} \tilde{p}-[C(N \tilde{x})-C((N-r) \tilde{x})]
$$

i.e., this time the large buyer will compensate the supplier for the fraction $\rho$ of the incremental costs created by increasing supply from $(N-r) \tilde{x}$ to $N \tilde{x}$. We thus find that the larger buyer can obtain more profits than two small buyers if the resulting incremental costs increase under-proportionally with the buyer's size. As is easily checked this holds if the cost function exhibits increasing unit costs. This holds, in particular, if $C$ is strictly convex.

\section{Generalization}

\footnotetext{
${ }^{23}$ Kesko/Tuko (EC/DGIV, 1999, Case No. IV/M.784) and Carrefour/Promodes (EC/DGIV, 2000, Case No. COMP/M.1684).
} 
Using the previous arguments we can now ask more generally when industry profits are strictly concave in the number of firms such that (11) holds. We find that this is the case if revenues are strictly concave and costs are strictly convex.

Proposition 2. If the cost function is strictly convex and the revenue function strictly concave, condition (11) holds, i.e., $\Pi_{n}^{*}$ is strictly concave in $n$. This also holds if costs are linear, but total capacity is sufficiently small and the revenue function is strictly concave.

Proof. Take first the case where capacity is unconstrained. It is now convenient to denote $\tilde{x}_{n}=x_{n}^{*} / n$. By noting that revenues and costs are twice continuously differentiable, $\tilde{x}_{n}$ is given by the first-order condition $R^{\prime}\left(\tilde{x}_{n}\right)-C^{\prime}\left(n \tilde{x}_{n}\right)=0$. Applying the implicit function theorem, we then obtain

$$
\frac{d \tilde{x}_{n}}{d n}=\frac{\tilde{x}_{n} C^{\prime \prime}\left(n \tilde{x}_{n}\right)}{R^{\prime \prime}\left(\tilde{x}_{n}\right)-n C^{\prime \prime}\left(n \tilde{x}_{n}\right)} .
$$

We next differentiate industry profits $\Pi_{n}^{*}=n \tilde{x}_{n} p\left(\tilde{x}_{n}\right)-C\left(n \tilde{x}_{n}\right)$ with respect to $n$. Using the envelope theorem, we obtain $d \Pi_{n}^{*} / d n=\tilde{x}_{n}\left[p\left(\tilde{x}_{n}\right)-C^{\prime}\left(n \tilde{x}_{n}\right)\right]$. Differentiating a second time and using the first-order condition for $\tilde{x}_{n}$, we obtain

$$
\frac{d^{2} \Pi_{n}^{*}}{d n^{2}}=-C^{\prime \prime}\left(n \tilde{x}_{n}\right) \tilde{x}_{n}\left[\tilde{x}_{n}+n \frac{d \tilde{x}_{n}}{d n}\right] .
$$

Substituting (13) into (14) this yields

$$
\frac{d^{2} \Pi_{n}^{*}}{d n^{2}}=-\frac{C^{\prime \prime}\left(n \tilde{x}_{n}\right)\left(\tilde{x}_{n}\right)^{2} R^{\prime \prime}\left(\tilde{x}_{n}\right)}{R^{\prime \prime}\left(\tilde{x}_{n}\right)-n C^{\prime \prime}\left(n \tilde{x}_{n}\right)}
$$

which is strictly negative if revenues are strictly concave and costs are strictly convex.

For the second assertion note first that if capacity is sufficiently constrained, the optimal choice satisfies $x_{n}^{*}=X$ for all $n$. Industry profits are then given by $\Pi_{n}^{*}=n R(X / n)-$ $C(X)$. Differentiating twice yields in this case $d \Pi_{n}^{*} / d n=R(X / n)-X R^{\prime}(X / n) / n$ and $d^{2} \Pi_{n}^{*} / d n=X^{2} R^{\prime \prime}(X / n) / n^{3}$. Q.E.D.

Having derived conditions when the creation of a larger buyer by a merger or by a sale of assets reduces the supplier's profits, it would be interesting to know more precisely when this reduction is larger or smaller. When is the discount enjoyed by a larger buyer more likely to be high or low? Denote a buyer's margin per supplied unit by $m_{i}$, i.e., $m_{i}=p\left(x_{N}^{*} / N\right)-\tau_{i}$. Denote also the first-order difference of industry profits by $\Delta_{n}^{*}=\Pi_{n}^{*}-\Pi_{n-1}^{*}$ for all $1 \leq n \leq N$. Hence, we obtain for the net surplus creation of a buyer with $r$ firms $\Pi_{N}^{*}-\Pi_{N-r}^{*}=\sum_{N-r+1}^{N} \Delta_{n}^{*}$. From (9) the ratio of two buyers' margins is then given by

$$
\frac{m_{i}}{m_{j}}=\frac{\sum_{N-r_{i}+1}^{N} \Delta_{n}^{*}}{\sum_{N-r_{j}+1}^{N} \Delta_{n}^{*}} \frac{r_{j}}{r_{i}} .
$$


When is the ratio $m_{i} / m_{j}$ likely to increase? Unfortunately, as the differences in industry profits $\Delta_{n}^{*}$ depend on the respective optimal supplies, there is little that can be said generally. In particular, we know from examples that increasing the curvature of the cost function will not necessarily result in an increase of $m_{i} / m_{j}$ for $r_{i}>r_{j}$. However, abstracting from this difficulty and focusing on the case with fixed capacity $X$, we can shed more light on the demand-side source of buyer power.

\section{Example 1: Constant-elasticity demand with fixed capacity}

Suppose that demand at each firm is given by the constant elasticity (inverse) demand function $p(x)=x^{-1 / \epsilon}$ with $\epsilon>1$. If $X$ is sufficiently small and production costs are zero, this yields the industry profits $\Pi_{n}^{*}=n(X / n)^{(\epsilon-1) / \epsilon}$. Focusing on the case with $r_{i}=2$ and $r_{j}=1$, we obtain from (15)

$$
\frac{m_{i}}{m_{j}}=\frac{1}{2}\left[1+\frac{(N-1)^{\frac{1}{\epsilon}}-(N-2)^{\frac{1}{\epsilon}}}{N^{\frac{1}{\epsilon}}-(N-1)^{\frac{1}{\epsilon}}}\right],
$$

which can be seen to be strictly increasing in the elasticity $\epsilon$. Hence, as demand becomes more elastic the ratio of the large buyer's to the small buyer's margin $m_{i} / m_{j}$ increases. Demand may become more elastic as competition at each individual outlet increases, e.g., due to the presence of more competitors or, in the case of retailing, due to the rise of other retail formats (e.g., e-commerce). If demand is less elastic, revenues lost due to a loss of a particular buyer do not increase that much with the buyer's size. Indeed, for $\varepsilon \rightarrow 1$ we obtain that $\Pi_{n}^{*}$ becomes linear in $n$, implying that in the limit larger buyers do no longer obtain a discount at all.

\section{Supplier Incentives and Welfare}

\subsection{Incentives}

The supplier can now take actions affecting either production costs or final demand. On the production side, he may consider to upgrade his production process, to extend his capacity, or to switch between different production and distribution technologies. On the demand side, the supplier may consider to introduce a new product or to improve the existing product's quality. The following analysis applies to the extent that these activities are not contractible. One application where this assumption seems to be particularly reasonable is again retailing, as retailers usually stock the products of many different suppliers. Writing detailed contracts regarding the improvement of products 
and production processes with all suppliers is surely not feasible for any given retailer. ${ }^{24}$

The main point which we want to make in this section is that the supplier's choice of non-contractible activities depends not on the overall size of his profits, but on the "composition" of his profits. In Section 6.2 we will use the generated insights to argue that the welfare consequences of buyer power may therefore be different from what is often asserted.

Recall that each buyer obtains the fraction $\rho$ of his net contribution to total industry profits. When selecting, for instance, a particular production technology, the supplier thus tries to increase total industry profits while keeping buyers' net contributions minimal. These two objectives should typically be conflicting. How this trade-off is resolved depends on the downstream market structure. We now treat strategies affecting the cost (or production) side and strategies affecting the revenue (or demand) side separately.

\section{Process innovation}

How does the formation of a larger buyer affect the way in which costs are shared between the supplier and his buyers? To answer this question we can use the insights gained when discussing the sources of buyer power. A buyer controlling $r$ firms must bear the fraction $\rho$ of the additionally generated costs $C\left(x_{N}^{*}\right)-C\left(x_{N-r}^{*}\right)$. Hence, if two firms merge the supplier loses twice the fraction $\rho$ of the incremental costs $C\left(x_{N}^{*}\right)-$ $C\left(x_{N-1}^{*}\right)$, but he gains the fraction $\rho$ of the incremental costs $C\left(x_{N}^{*}\right)-C\left(x_{N-2}^{*}\right)$. In other words, after the merger the supplier can "roll over" more of the costs generated by increasing production at relatively low quantities, i.e., from $x_{N-2}^{*}$ to $x_{N-1}^{*}$, and less of the costs generated by increasing production at relatively high quantities, i.e., from $x_{N-1}^{*}$ to $x_{N}^{*}$. Following a merger he will thus have higher incentives to reduce incremental costs incurred at high production volumes and lower incentives to reduce incremental costs incurred at low production volumes.

This logic extends to mergers where buyers control more than one firm. Moreover, inspecting (10) reveals that it also extends to the case where a smaller buyer sells firms to a larger buyer. We can thus make the following observation. ${ }^{25}$

Observation 1. After the creation of a larger buyer, e.g., through a merger or a sale of assets by a smaller buyer, the supplier focuses more on reducing incremental costs incurred at high production volumes and less on reducing incremental costs incurred at low production volumes.

We next illustrate Observation 1 with an example.

\footnotetext{
${ }^{24}$ Additionally, the presence of multiple retailers may generate public-good problems, e.g., on how to split the investment outlays.

${ }^{25}$ Observation 1 is related to Stole and Zwiebel (1996) who find that it matters for a firm's choice of technology whether workers are unionized or whether they negotiate independently.
} 


\section{Example 2: Process innovation}

Suppose there are $N=3$ buyers. Each buyer controls a single firm with a final demand given by $p(x)=1-x$. We specify the sharing rule $\rho=1 / 2$. Before negotiations start the supplier can choose between two production technologies $A$ and $B$, which are associated with the cost functions $C_{A}(x)=\frac{1}{2} c_{A} x^{2}$ and $C_{B}(x)=c_{B} x$, where we specify $c_{A}=1$ and require $0<c_{B}<1$. A simple interpretation is that the more innovative technology $B$ can be more flexibly adjusted to higher production quantities.

Under the linear technology $B$ we obtain $\Pi_{n}^{*}=n\left(1-c_{B}\right)^{2} / 4$, while under the quadratic technology $A$ we obtain $\Pi_{n}^{*}=n /[2(2+n)]$. With linear costs the supplier's profits, which are not affected by the downstream market structure, are by Proposition 1 equal to $V^{B}=3\left(1-c_{B}\right)^{2} / 8$. In the quadratic case denote the respective profits with $I$ independent buyers by $V_{I}^{A}$, where we obtain $V_{3}^{A}=9 / 40$ and $V_{2}^{A}=5 / 24$. It is easily seen that $V_{2}^{A}<V_{3}^{A}$ holds, which confirms Corollary 1.

Comparing next $V^{B}$ with $V_{3}^{A}$ and $V_{2}^{A}$, we can see that the supplier has more incentives to implement technology $B$ if he faces only two independent buyers. One way to formalize this is to assume that switching to the more flexible technology $B$ requires some upfront investment. If he faces $I$ independent buyers, the supplier is only prepared to switch technologies if these costs do not surpass the threshold $V^{B}-V_{I}^{A}$. This cost threshold is strictly higher if the supplier faces $I=2$ instead of $I=3$ buyers. The example, therefore, confirms Observation 1. The emergence of a large retailer increases the supplier's incentives to adopt technology $B$, which -compared with technology $A$ exhibits lower incremental costs at relatively high output levels and larger incremental costs at relatively low output levels.

\section{Product innovation}

Let us now consider non-contractible investment strategies that affect the revenue (or demand) side of the industry. We can now rely on the insights obtained when discussing how buyer power may originate from characteristics of final demand. If the downstream market is fully fragmented, the supplier's outside option in negotiations depends only on how well he can cope with the loss of a single market (firm). In contrast, if two firms merge, the supplier faces also the threat of losing two markets simultaneously. Hence, after the merger of two firms the supplier's profits depend more on how revenues change when increasing supply at each remaining firm from $x_{N-1}^{*} /(N-1)$ to $x_{N-2}^{*} /(N-2)$ and less on how revenues change when increasing supply from $x_{N}^{*} / N$ to $x_{N-1}^{*} /(N-$ 1). ${ }^{26}$ The merger thus makes the supplier focus more on incremental revenues generated at relatively higher supply levels. As this logic extends again to any merger and, by

\footnotetext{
${ }^{26}$ Note that $x_{n}^{*} / n$ is strictly decreasing for convex costs (see Proposition 2).
} 
inspection of (10), also to the sale of assets from a smaller to a larger buyer, we can make the following observation.

Observation 2. After the creation of a larger buyer, e.g., through a merger or a sale of assets by a smaller buyer, the supplier focuses more on increasing incremental revenues at high quantities and less on increasing incremental revenues at low quantities.

We provide again an illustration.

\section{Example 3: Product innovation}

Suppose the supplier has fixed capacity $X$ and incurs no production costs. We specify again that there are $N=3$ buyers each controlling a single firm, and that the sharing rule $\rho=1 / 2$ applies. The supplier can influence the "versatility" of his input. To capture this, suppose that at each market two goods can be supplied, which both require per unit of output one unit of the same input. The extent to which these goods can be differentiated depends on the versatility of the input. Precisely, suppose that each firm faces for good $x_{j}$, where $j=1,2$, the inverse demand $p_{j}=1-x_{j}-\gamma x_{k}$, with $k \neq j$ and $0 \leq \gamma \leq 1 .{ }^{27}$ The supplier can choose between two variants $A$ and $B$ with respective versatilities $\gamma_{A}$ and $\gamma_{B}$. Product differentiation is larger with variant $B$, i.e., $0 \leq \gamma_{B}<\gamma_{A} \leq 1$.

If capacity is sufficiently small such that it is binding even if only a single market is supplied, we obtain for all $n$ the industry profits $\Pi_{n}^{*}=X[1-X(1+\gamma) /(2 n)]$. If the downstream market is fragmented with $I=3$ independent buyers, we obtain from Proposition 1 that the supplier's profits equal $X[1-7 X(1+\gamma) / 24]$. If two firms merge the supplier's profits equal $X[1-3 X(1+\gamma) / 8]$. As previously we denote profits realized under the respective variants by $V_{I}^{A}$ and $V_{I}^{B}$, where $I=2,3$. The supplier's gain from implementing the more versatile input variant $B$ instead of variant $A$ equals now $V_{3}^{B}-V_{3}^{A}=7 X^{2}\left(\gamma_{A}-\gamma_{B}\right) / 24$ if the downstream industry is fragmented and $V_{2}^{B}-V_{2}^{A}=$ $3 X^{2}\left(\gamma_{A}-\gamma_{B}\right) / 8$ if two buyers have merged. Comparison of both threshold values yields that the supplier is prepared to invest more to produce the more versatile variant $B$ if the downstream industry becomes more concentrated. Intuitively, by choosing the more versatile variant $B$ the supplier can more easily divert large supply quantities away from one buyer to others without significant reductions in retail prices. This ability is important to sustain the value of the supplier's outside option when negotiating with a large buyer.

\footnotetext{
${ }^{27}$ While this set-up is not fully captured by our model, where we assumed that one unit of input is transferred into one unit of an homogeneous output, it can be easily brought in line as follows. Given the specified demand function, a firm will optimally allocate supply symmetrically over the two final products. This generates for given $x$ at each firm the revenue function $R(x)=2(1-(1-\gamma) x / 2)$.
} 


\subsection{Welfare Effects of Buyer Power}

In this section we address the often expressed view that the exercise of buyer power is detrimental to social welfare as it reduces suppliers' investments into product and process innovation. As already noted in the introduction this argument was repeatedly expressed in recent policy debates. The underlying presumption is that a reduction in the supplier's profits will also reduce his incentives to make investments. According to our view, this argument has two flaws.

Our first criticism stems from the previous observation that a supplier's incentives to engage in product and process innovation are more driven by the composition of the supplier's profits and less by its absolute level. ${ }^{28}$ As argued in the preceding section, the emergence of larger buyers makes the supplier focus more on reducing incremental production costs at high production volumes and on increasing incremental revenues at high supplied quantities. This shift may increase the supplier's incentives to perform certain activities of product and process innovation. By means of our previous example we will further demonstrate for the case of process innovation that the formation of larger buyers may thus increase welfare. This follows as the supplier's resulting choice of technology is likely to increase overall supply, which is beneficial as by ignoring consumer rents firms will typically choose too low quantities for any given technology.

The second flaw in the above argument is more immediate and concerns, in particular, product improvement. The argument implicitly asserts that higher investment incentives are always beneficial. Since Spence $(1975,1976)$ it is, however, well known that firms' incentives to improve a product's quality or to introduce differentiated variants may sometimes be too high (see Tirole 1988 for an overview). While it is the marginal consumer's valuation that determines a firm's optimal quality choice, from a welfare perspective it should be the average valuation of served consumers. This will be illustrated in our example of product innovation where the formation of a larger buyer can induce the supplier to undertake a higher investment that is not socially beneficial.

\section{Example 2 (continued): Process innovation}

Consider our previous example of process innovation. Recall that the choice of the more flexible technology $B$ may require an up-front investment by the supplier. If he faces $I$ independent buyers, he is only prepared to switch if these costs do not exceed the threshold $k_{I}=V^{B}-V_{I}^{A}$. Recall that $k_{2}>k_{3}$ holds, i.e., the supplier is more prepared to switch after two of the three firms have merged. In particular, we obtain $k_{2}=$ $3\left(1-c_{B}\right)^{2} / 8-5 / 24$, where $c_{B}$ denotes the constant marginal costs under technology $B$. Clearly, technology $B$ will only be chosen as long as $c_{B}$ is not too large. In the following

\footnotetext{
${ }^{28}$ Admittedly, total profits play a more important role when considering, for instance, potential entry.
} 
we restrict attention to this case by requiring that $c_{B}$ does not exceed the threshold $\bar{c}_{B}=1-\frac{1}{3} \sqrt{5}$.

Turn now to the consideration of total welfare, i.e., the sum of consumer rents and industry profits, which we denote by $W{ }^{29}$ We obtain that, given the chosen supplies $x_{N}^{*}$, welfare equals $W^{A}=9 / 25$ under technology $A$ and $W^{B}=9\left(1-c_{B}\right)^{2} / 8$ under technology $B$. This yields the threshold $k^{*}=W^{B}-W^{A}$ such that from a welfare perspective technology $B$ should be chosen if the additional up-front costs do not exceed $k^{*}$. Comparing thresholds we finally find that $k^{*}>k_{2}$ holds if $6\left(1-c_{B}\right)^{2} / 8>91 / 600$ is satisfied. This holds for all values $c_{B} \leq \bar{c}_{B}$. Hence, from a welfare perspective the supplier should switch technologies more often than he does even in the case where he faces a larger buyer. Moreover, if the costs of switching to the more flexible technology fall into the interval $\left(k_{2}, k_{3}\right)$, the buyer merger strictly increases welfare by inducing the supplier to undertake the investment.

This example, therefore, supports our first criticism. Buyer power may unfold socially beneficial effects by shifting suppliers' incentives for cost reductions to high levels of production. As marginal cost reductions transform into an expansion of total output and thereby an increase in consumer surplus, buyer power may also increase social welfare. ${ }^{30}$

\section{Example 3 (continued): Product innovation}

We denote by $k_{I}$ the maximum up-front costs the supplier is willing to pay in order to switch from variant $A$ to the more versatile variant $B$, if there are $I$ independent buyers. We obtained $k_{2}=3 X^{2}\left(\gamma_{A}-\gamma_{B}\right) / 8$ and $k_{3}=7 X^{2}\left(\gamma_{A}-\gamma_{B}\right) / 24$, where $k_{2}>k_{3}$ follows from $\gamma_{A}>\gamma_{B}$. The realized welfare is $W=X[1-X(1+\gamma) /(4 n)]$ if the versatility is given by $\gamma$ and if $n$ firms are supplied. ${ }^{31}$ From a welfare perspective there should be a switch to the more versatile input $B$ as long as the additional costs do not exceed $k^{* *}=X^{2}\left(\gamma_{A}-\gamma_{B}\right) / 12$. This threshold falls short of both $k_{2}$ and $k_{3}$. Hence, in this example the supplier's incentives to choose a more versatile input are always too high from a welfare perspective. If the costs of choosing the more versatile input fall into the interval $\left(k_{3}, k_{2}\right)$, welfare is reduced by a buyer merger as this induces the supplier to undertake the investment even though this is not socially beneficial.

This example, therefore, supports our second criticism. With product innovation the formation of larger buyers may reduce welfare, but this may be due to an increase in

\footnotetext{
${ }^{29}$ We hereby assume that the inverse demand function is generated by quadratic utility function of a representative consumer, which is given by $x-\frac{1}{2} x^{2}$.

${ }^{30}$ For $c_{B} \leq \bar{c}_{B}$ it is immediate that equilibrium supply is strictly larger under technology $B$ than under technology $A$.

${ }^{31}$ We hereby assume that the inverse demand function is generated by a quadratic utility function of a representative consumer of the form $\left(x_{1}+x_{2}\right)-\frac{1}{2}\left(x_{1}^{2}+x_{2}^{2}\right)-\gamma x_{1} x_{2}$.
} 
investment incentives and not due to a reduction.

\section{Conclusion}

This paper studies the impact of buyer power on a supplier's profits and his incentives to undertake non-contractible activities. We first isolate two sources of buyer power. If revenues at each downstream firm are strictly concave, larger buyers can threaten the supplier with a loss in revenues that grows over-proportionally with size. If production costs are convex, additional costs incurred by serving an individual buyer increase under-proportionally with his size. While facing a larger buyer decreases the supplier's profits, we argue that his incentives to undertake product or process innovation may often increase. Facing a larger buyer the supplier will focus more on reducing incremental costs incurred at high volumes and he will focus more on increasing incremental revenues generated at high supply levels. As a reduction in marginal costs at high output levels may increase total supply and thus consumer rents, a supplier facing larger buyers may more often than not choose a production technology that increases welfare. In contrast, in the case of product innovation we showed that it is quite likely that the formation of larger buyers reduces welfare by creating too high investment incentives and not by reducing incentives.

Taking the broader picture of horizontal merger control, our findings qualify the commonly held belief that the leverage of large buyers in contract negotiations negatively affects suppliers' investment incentives and, by doing so, welfare. As we found that the opposite may happen, our analysis also calls for a more systematic assessment of dynamic efficiency concerns in merger control. While the "innovation markets" concept (see Gilbert and Sunshine 1995) is an important step in that direction, our paper demonstrates that not only horizontal concentration between innovating firms but also concentration along the entire value chain may matter.

\section{References}

Balto, D.A. (1999), Supermarket Merger Enforcement, Antitrust Report, August 1999.

Bernheim, B.D. and Whinston, M.D. (1986), Menu Auctions, Resource Allocation, and Economic Influence, Quarterly Journal of Economics 101, 1-31.

Binmore, K., Rubinstein, A., and Wolinsky, A. (1986), The Nash Bargaining Solution in Economic Modelling, Rand Journal of Economics 17, 176-188. 
Blair, R.D. and J.L. Harrison (1993), Monopsony: Antitrust Law and Economics, Princeton University Press, Princeton, New Jersey.

Bolton, P. and Whinston, M.A. (1993), Incomplete Contracts, Vertical Integration and Supply Assurance, Review of Economic Studies 60, 121-148.

Bowley, A.L. (1928), Bilateral Monopoly, Economic Journal 38, 651-659.

Chipty, T. and Snyder, C.M. (1999), The Role of Firm Size in Bilateral Bargaining: A Study of the Cable Television Industry, Review of Economics and Statistics 81, 326-340.

Choi, J.P. and Yi, S.-S. (2000), Vertical Foreclosure with the Choice of Input Specifications, Rand Journal of Economics 31, 717-743.

Cotterill, R.M. (1997), The Food Distribution System of the Future: Convergence Towards the US or UK Model?, Agrobusiness 12, 123-135.

Dobson, P. and Waterson, M. (1997), Countervailing Power and Consumer Prices, Economic Journal 107, 418-430.

Ellison, S.F. and Snyder, C.M. (2001), Countervailing Power in Wholesale Pharmaceuticals, Working Paper 01-27, Massachusetts Institute of Technology, Cambridge, MA.

EC (1999), Buyer Power and its Impact on Competition in the Food Retail Distribution Sector of the European Union, Report produced for the European Commission, DG IV, Brussels.

Felli, L. and Roberts, K. (2001), Does Competition Solve the Hold-up Problem?, STICERD Theoretical Economics Discussion Paper No. TE/01/414, London School of Economics, London.

FTC (2000), Entering the 21st Century: Competition Policy in the World of B2B Electronic Marketplaces, Report by the Federal Trade Commission Staff, Washington, D.C.

FTC (2001), Report on the Federal Trade Commission Workshop on Slotting Allowances and Other Marketing Practices in the Grocery Industry, Report by the Federal Trade Commission Staff, Washington, D.C.

Galbraith, J.K. (1952), American Capitalism: The Concept of Countervailing Power, Boston: Houghton Mifflin. 
Gaynor, M. and Haas-Wilson, D. (1999), Change, Consolidation, and Competition in Health Care, Journal of Economic Perspectives 13, 141-164.

Gilbert, R. and Sunshine, S.C. (1995), Incorporating Dynamic Efficiency Concerns in Merger Analysis: The Use of Innovative Markets, Antitrust Law Journal 63, 569-601.

Grossman, S.J. and Hart, O.D. (1986), The Costs and Benefits of Ownership: A Theory of Vertical and Lateral Integration, Journal of Political Economy 94, 691-719.

Grout, P. (1984), Investment and Wages in the Absence of Binding Contracts, Econometrica 52, 449-460.

Hendricks, K. and McAfee, R.P. (2000), A Theory of Bilateral Oligopoly with Applications to Vertical Mergers, Mimeo, University of Texas, Austin.

Horn, H. and Wolinsky, A. (1988a), Bilateral Monopolies and Incentives for Merger, Rand Journal of Economics 19, 408-419.

Horn, H. and Wolinsky, A. (1988b), Worker Substitutability and Patterns of Unionisation, Economic Journal 98, 484-497.

Inderst, R. and Wey, C. (2001), Market Structure, Bargaining, and Technology Choice in Bilaterally Oligopolistic Industries, CEPR Discussion Paper No. 2981, London.

Innes, R. and Sexton, R.J. (1993), Customer Coalitions, Monopoly Price Discrimination and Generic Entry Deterrence, European Economic Review 37, 1569-1597.

Katz, M.L. (1987), The Welfare Effects of Third Degree Price Discrimination in Intermediate Goods Markets, American Economic Review 77, 154-167.

Kühn, K.-U. (1997), Nonlinear Pricing in Vertically Related Duopolies, Rand Journal of Economics 28, 37-62.

Kolasky, W.J. (2002), Coordinated Effects in Merger Review: From Dead Frenchmen to Beautiful Minds and Mavericks, U.S. Department of Justice, Washington.

Kranton, R.E. and Minehart, D.F. (2000), Networks vs. Vertical Integration, Rand Journal of Economics 31, 570-601.

Marx, L.M. and Shaffer, G. (2001), Upfront Payments and Exclusion, Mimeo, University of Rochester. 
McLaren, J. (2000), Globalization and Vertical Structure, American Economic Review 90, 1239-54.

Morgan, J.M. (1949), Bilateral Monopoly and the Competitive Output, Quarterly Journal of Economics 63, 371-91.

O'Brien, D.P. and Shaffer, G. (1997), Nonlinear Supply Contracts, Exclusive Dealing, and Equilibrium Market Foreclosure, Journal of Economics and Management Strategy 6, 755-785.

OECD (1981), Buying Power: The Exercise of Market Power by Dominant Buyers, Report of the Committee of Experts on Restrictive Business Practices, OECD, Paris.

OECD (1999), Buying Power of Multiproduct Retailers, Series Roundtables on Competition Policy DAFFE/CLP(99)21, OECD, Paris.

OFT (1998), The Welfare Consequences of the Exercise of Buyer Power, Office of Fair Trading Research Paper No. 16, London.

Pitofsky, R. (1997), Thoughts on "Leveling the Playing Field" in Health Care Markets, Federal Trade Commission (February 13, 1997), Washington D.C.

Porter, M.E. (1976), Interbrand Choice, Strategy, and Bilateral Market Power, Harvard University Press, Cambridge, MA.

Robinson, T. and Clarke-Hill, C.M. (1995), International Alliances in European Retailing, in: P.J. McGoldrick and G. Davies (eds.), International Retailing: Trends and Strategies, Financial Times Pitman Publishing.

Scheffman, D.T. and Spiller, P.T. (1992), Buyer's Strategies, Entry Barriers, and Competition, Economic Inquiry 30, 418-436.

Scherer, F.M. and Ross, D. (1990), Industrial Market Structure and Economic Performance, 3rd Edition, Houghton Mifflin Comp., Boston, MA.

Schwartz, M. (1999), Buyer Power Concerns and the Aetna-Prudential Merger, U.S. Department of Justice (October 20, 1999), Washington D.C.

Segal, I. (2001), Collusion, Exclusion, and Inclusion in Random-Order Bargaining, Mimeo, Stanford University, Stanford, CA.

Snyder, C.M. (1996), A Dynamic Theory of Countervailing Power, Rand Journal of Economics 27, 747-769. 
Sorensen, A.T. (2001), Insurer-Hospital Bargaining: Negotiated Discounts in PostDeregulation Conneticut, Mimeo, University of California, San Diego.

Spence, M. (1975), Monopoly, Quality and Regulation, Bell Journal of Economics 6, $417-29$

Spence, M. (1976), Product Differentiation and Welfare, American Economic Review $66,407-14$.

Spulber, D.F. (2002), Market Microstructure and Incentives to Invest, Journal of Political Economy 110, 352-381.

Stigler, G.J. (1954), The Economist Plays with Blocs, American Economic Review 44, $7-14$.

Stigler, G.J. (1964), A Theory of Oligopoly, Journal of Political Economy 62, 44-66.

Stole, L.A. and Zwiebel, J. (1996), Organizational Design and Technology Choice under Intrafirm Bargaining, American Economic Review 86, 195-222.

Sullivan, M.W. (1999), Slotting Allowances and the Market for New Products, Journal of Law and Economics 40, 461-493.

Tirole, J. (1988), The Theory of Industrial Organization, MIT Press, Cambridge, MA.

von Ungern-Sternberg, T. (1996), Countervailing Power Revisited, International Journal of Industrial Organization 14, 507-520.

Waterson, M. (1980), Price-cost Margins and Successive Market Power, Quarterly Journal of Economics 94, 135-150. 
Bücher des Forschungsschwerpunkts Markt und politische Ökonomie

Books of the Research Area Markets and Political Economy

Andreas Stephan

Essays on the Contribution of Public Infrastructure to Private: Production and its Political

Economy

2002, dissertation.de

Hans Mewis

Essays on Herd Behavior and Strategic

Delegation

2001, Shaker Verlag

Andreas Moerke

Organisationslernen über Netzwerke - Die

personellen Verflechtungen von

Führungsgremien japanischer

Aktiengesellschaften

2001, Deutscher Universitäts-Verlag

Silke Neubauer

Multimarket Contact and Organizational Design

2001, Deutscher Universitäts-Verlag

Lars-Hendrik Röller, Christian Wey (Eds.)

Die Soziale Marktwirtschaft in der neuen

Weltwirtschaft, WZB Jahrbuch 2001

2001, edition sigma

Michael Tröge

Competition in Credit Markets: A Theoretic

Analysis

2001, Deutscher Universitäts-Verlag

Tobias Miarka

Financial Intermediation and Deregulation:

A Critical Analysis of Japanese Bank-Firm-

Relationships

2000, Physica-Verlag

Rita Zobel

Beschäftigungsveränderungen und organisationales Lernen in japanischen Industriengesellschaften

2000, Humboldt-Universität zu Berlin

http://dochost.rz.hu-berlin.de/dissertationen/zobel-

rita-2000-06-19

Jos Jansen

Essays on Incentives in Regulation and Innovation

2000, Tilburg University

Ralph Siebert

Innovation, Research Joint Ventures, and

Multiproduct Competition

2000, Humboldt-Universität zu Berlin

http://dochost.rz.hu-berlin.de/dissertationen/siebert-

ralph-2000-03-23/

Damien J. Neven, Lars-Hendrik Röller (Eds.)

The Political Economy of Industrial Policy in

Europe and the Member States

2000, edition sigma
Jianping Yang

Bankbeziehungen deutscher Unternehmen: Investitionsverhalten und Risikoanalyse 2000, Deutscher Universitäts-Verlag

Christoph Schenk

Cooperation between Competitors -

Subcontracting and the Influence of Information, Production and Capacity on Market Structure and Competition

1999, Humboldt-Universität zu Berlin

http://dochost.rz.hu-berlin.de/dissertationen/schenk-

christoph-1999-11-16

Horst Albach, Ulrike Görtzen, Rita Zobel (Eds.)

Information Processing as a Competitive

Advantage of Japanese Firms

1999, edition sigma

Dieter Köster

Wettbewerb in Netzproduktmärkten

1999, Deutscher Universitäts-Verlag

Christian Wey

Marktorganisation durch Standardisierung: Ein

Beitrag zur Neuen Institutionenökonomik des

Marktes

1999, edition sigma

Horst Albach, Meinolf Dierkes, Ariane Berthoin Antal, Kristina Vaillant (Hg.)

Organisationslernen - institutionelle und

kulturelle Dimensionen

WZB-Jahrbuch 1998

1998, edition sigma

Lars Bergman, Chris Doyle, Jordi Gual, Lars

Hultkrantz, Damien Neven, Lars-Hendrik Röller,

Leonard Waverman

Europe's Network Industries: Conflicting

Priorities - Telecommunications

Monitoring European Deregulation 1

1998, Centre for Economic Policy Research

Manfred Fleischer

The Inefficiency Trap

Strategy Failure in the

German Machine Tool Industry

1997, edition sigma

Christian Göseke

Information Gathering and Dissemination

The Contribution of JETRO to

Japanese Competitiveness

1997, Deutscher Universitäts-Verlag 
Fredrik Andersson

Kai A. Konrad

Lars-Hendrik Röller

Christian Wey

Talat Mahmood Klaus Schömann

Talat Mahmood Klaus Schömann

Jos Jansen

Jos Jansen

Günter Franke Harris Schlesinger Richard C. Stapleton

Tomaso Duso

Johan Lagerlöf

Paul Heidhues

Olivier Cadot Lars-Hendrik Röller Andreas Stephan

Justus Haucap

Christian Wey

Heidrun C. Hoppe Emre Ozdenoren

Rainer Nitsche

Daniel Krähmer

J. Peter Murmann

Kai A. Konrad

Robert Nuscheler

Fredrik Andersson Kai A. Konrad
Human Capital Investment and Globalization in Extortionary States

Merger Control in the New Economy

Die Determinanten der Mirgrationsentscheidung von IT-Hochschulabsolventen aus Pakistan Empirische Befunde zur Ausgestaltung der deutschen „Green Card“

The Determinants of the Migration Decision of ITgraduates from Pakistan: Empirical Evidence for the Design of a German "Green Card"

The Effects of Disclosure Regulation on Innovative Firms: Common Values

The Effects of Disclosure Regulation on Innovative Firms: Private Values

Multiplicative Background Risk

On the Politics of the Regulatory Reform:

Econometric Evidence from the OECD Countries

On the Desirability of an Efficiency Defense in

Merger Control

Contribution to Productivity or Pork Barrel? The Two Faces of Infrastructure Investment

Unionization Structures and Firms' Incentives for Productivity Enhancing Investments

Intermediation in Innovation

On the Effectiveness of Anti-Predation Rules

Entry and Experimentation in

Oligopolistic Markets for Experience Goods

The Coevolution of Industries and National Institutions: Theory and Evidence

Terrorism and the State

Physician Reimbursement, Time-Consistency and the Quality of Care

Taxation and Education Investment in the Tertiary Sector
FS IV $02-06$

FS IV $02-11$

FS IV $02-12$

FS IV $02-15$



FS IV $02-02$ 
Jan Boone

Kai A. Konrad

Helmut Bester

Kai A. Konrad

Kjell Erik Lommerud Bjørn Sandvik

Odd Rune Straume

Steffen Huck Vicki Knoblauch Wieland Müller

Ralph Siebert

Jürgen Bracht

Saul Lach

Eyal Winter

Steffen Huck

Kai A. Konrad

Daniel Krähmer

Thomas Knaus

Robert Nuscheler

Kurt R. Brekke

Robert Nuscheler

Odd Rune Straume

Kai A. Konrad

Sebastian Kessing

Sebastian Kessing

Michal Grajek

Robert M. Adams Lars-Hendrik Röller

Robin C. Sickles

Tomaso Duso

Damien J. Neven Lars-Hendrik Röller

Tomaso Duso Astrid Jung
'Be nice, unless it pays to fight': A New Theory of

Price Determination with Implications for

Competition Policy

Altruism and Envy in Contests:

An Evolutionarily Stable Symbiosis

Delay in Contests

Good Jobs, Bad Jobs and Redistribution

On the Profitability of Collusion in Location Games

Learning by Doing and Multiproduction Effects over the Life Cycle: Evidence from the

Semiconductor Industry

Modeling Oligopolistic Price Adjustment in Micro

Level Panel Data

Strategic Trade Policy and the Home Bias in Firm

Ownership Structure

Delegation versus Authority

Incomplete Risk Adjustment and Adverse

Selection in the German Public Health Insurance System

Quality and Location Choices under Price

Regulation

Inverse Campaigning

A Note on the Determinants of Labour Share Movements

Employment Protection and Product Market Competition

Identification of Network Externalities in Markets for Non-Durables

Market Power in Outputs and Inputs: An Empirical Application to Banking

The Political Economy of European Merger Control: Evidence using Stock Market Data

Market Conduct and Endogenous Lobbying: Evidence from the U.S. Mobile Telecommunications Industry
FS IV $02-20$

FS IV $02-21$

FS IV $02-22$

FS IV $02-28$

FS IV $02-29$

FS IV $02-18$

FS IV $02-19$

FS IV $02-23$

FS IV $02-24$

FS IV $02-25$

FS IV $02-26$

FS IV $02-27$

FS IV $02-30$

FS IV $02-31$

FS IV $02-32$

FS IV $02-33$

FS IV $02-34$

FS IV $02-35$ 
Anette Boom Investments in Electricity Generating Capacity under Different Market Structures and with Endogenously Fixed Demand

Kai A. Konrad Wolfram F. Richter

Stergios Skaperdas

Johan Lagerlöf

Roman Inderst Christian Wey
Zur Berücksichtigung von Kindern bei umlagefinanzierter Alterssicherung

Restraining the Genuine Homo Economicus: Why the Economy cannot be divorced from its Governance

Insisting on a Non-Negative Price: Oligopoly, Uncertainty, Welfare, and Multiple Equilibria

Buyer Power and Supplier Incentives
SP || $2003-02$

SP || $2003-03$

SP || $2003-04$

SP || $2003-05$ 
Bei Ihren Bestellungen von WZB-Papers schicken

Sie bitte unbedingt einen an Sie adressierten Auf-

kleber mit sowie je paper eine Briefmarke im Wert

von 0,51 Euro oder einen "Coupon Reponse Inter-

national " (für Besteller aus dem Ausland)
Please send a self addressed label and postage stamps in the amount of 0.51 Euro or a "CouponReponse International" (if you are ordering from outside Germany) for each WZB-paper requested

Absender / Return Address:

Wissenschaftszentrum Berlin

für Sozialforschung

Presse- und informationsreferat

Reichpietschufer 50

D-10785 Berlin-Tiergarten

Hiermit bestelle ich folgende(s)

Discussion paper(s):

Please send me the following Discussion paper(s):

Bestell-Nr. / Order no.

Autor/in, Kurztitel /Author(s) / Title(s) in brief 